\title{
The Complex Relation of Self-determination to Destiny in Oedipus
}

\section{Tyrannos}

\author{
Ruoqi $\mathrm{Li}^{1}$ \\ ${ }^{1}$ The High School Affiliated to Fudan University, Shanghai, China \\ Correspondence: Ruoqi Li, WLSA Academy, The High School Affiliated to Fudan University, No.2 Zhengxi \\ Road, Yangpu District, Shanghai, China. 200433. Tel: 86-186-3820-0057. E-mail: RuoqiLi6699@163.com
}

\author{
Received: September 5, 2015 Accepted: September 26, 2015 Online Published: November 29, 2015 \\ doi:10.5539/ells.v5n4p115 URL: http://dx.doi.org/10.5539/ells.v5n4p115
}

\begin{abstract}
Oedipus Rex, one of the three famed Theban tragedies by the Greek dramatist Sophocles, vividly portrays the complex and often troubling theme of humanity's relationship to fate. By detailing the way in which Oedipus, king of Thebes, is reduced by the cruelty of predestination into a puppet with no semblance of control over the course of his own life, Sophocles seems to cast doubt on, not only the effectiveness, but also the meaning of self-control. Thus, freedom of choice, humanity's final assertion of independence, appears to dissolve into hollow mockery. But even then, Sophocles confirms the fundamental significance of the self-knowledge and dignity that comes from struggling against tyrannical destiny. It is this dignity that sustains king Oedipus through his terrible ordeal so that he comes out of it tortured but not destroyed. It is also this elevation that adds to a tale of endless victimization a whole new dimension of complexity and imbues the words with a touch of tragic and transfiguring sublimity.
\end{abstract}

Keywords: Oedipus Rex, tragedy, destiny, freedom of will

\section{Introduction}

Praised by Cicero as the "Homer of drama", Sophocles was a tragedian who lived in Athens during the fifth century B.C.E. Oedipus Rex, one of his most representative works, was once hailed by the Greek philosopher Aristotle as the "perfect tragedy", intricately crafted and dignified, in his defense of tragedy in the Poetics. The plot of Oedipus Rex comes from Greek mythology. Originally the son of Laius and Jocasta, the king and queen of Thebes, Oedipus was born cursed by the god Apollo to kill his father and defile his mother. Hearing the oracle, Laius ordered a shepherd to take the infant Oedipus and to cast him away on the mount of Cithaeron. Out of sympathy, the shepherd saved the child, who ultimately became the adopted son of the king of Corinth. As a young man, Oedipus heard of his terrible fate from the Oracle of Delphi. Unaware of his true origin and bent upon evading the blow of destiny, he left Corinth and his adoptive parents to journey to Thebes. At a crossroads, Oedipus was provoked by a rude traveller, who tried to force him off the road; in the heat of anger, Oedipus struck and killed the old man, who later turned out to be Laius, his true father. At Thebes, Oedipus encountered the sphinx, and by answering her riddle correctly saved the Thebans from her curse. The Thebans, now without a king, warmly invited Oedipus to take the throne. As the new king, Oedipus naturally wedded Jocasta, Laius' widow and his real mother, and thus carried out destiny's plan. At the start of the play, Oedipus had been the king of Thebes for 16 years and was then attempting to save his city from the throes of pestilence. Hearing from his brother-in-law Creon that the gods were abandoning Thebes because the murderer of the previous king, Laius, had gone unpunished and had polluted the city, Oedipus disregarded all obstacles to find out the identity of that murderer. In his determination to save his city, Oedipus ultimately found out the reality of his identity. To rid Thebes of his terrible pollution and to punish himself, Oedipus blinded his eyes and went into exile, never to return to his beloved city Thebes.

As a fine example of the ancient Greek tragedies which feature the conflict between free will and destiny, Oedipus Rex portrays this clash in moving strokes and closely ponders upon its many implications about what it means to live and transcend. Although the concepts of preordained destiny and self-determination appear to be incompatible, Greek tragedian Sophocles demonstrates in his Theban play Oedipus Tyrannos that there is a logical, albeit complex and paradoxical, connection between fate and one's power to govern oneself. In a tale full of irony, Sophocles casts doubt not only on the power a person's will exert over destiny, but on the reality of free 
will itself.

\section{Oedipus Had No Power over the Determination and Unravelling of His Destiny}

\subsection{Destiny Precedes and Exists Independently of Self-Determination}

The first message that arises clearly from Oedipus Tyrannos is that destiny precedes and exists independently of self-determination. In the case of Oedipus, his fated curse of patricide and incest was brought onto him by his ancestor Cadmus' offence against the gods (Ellis \& Horne, 2010), over which he could have had no control. His destiny was determined by external agents before he was born and far before his individual will even existed, a testament to the essentially uncontrollable nature of fate.

\subsection{Oedipus Had No Control over What Happened to His Infant Self}

Even so, the reader may observe that, if one has no say in the determination of one's destiny, surely one has power over its unraveling. Sophocles denies that. Even after Oedipus was born and his destiny was laid out before him, there was still a chance for Oedipus to be saved from that destiny: namely, by not living that life at all. Laius, the loving father that he was, was obviously aware of this possibility of escaping from the curse and ordered young Oedipus, shackled and helpless, to be taken to the Cithaeron mountain to be left to die. If that had gone according to plan, Oedipus would have died an infant innocent of the taint of his future crimes. The soft-hearted shepherd, however, feeling sorry for the infant, gave it away and allowed it a chance to live, and in doing so preserved Oedipus for a destiny, as Oedipus later lamented, "worse than death". (Sophocles, 2007, p. 128) Oedipus had no control back then over what happened to his infant self-he was completely at the mercy of the shepherd's kindness, but was left to suffer the consequences.

\subsection{Oedipus' Efforts to Circumvent Destiny Only Contributed to Its Triumph}

Having now established destiny as a potent rival that won the first fight before Oedipus had stepped into the arena, Sophocles goes on to describe the profoundly ironical subjugation of free will to preordained destiny. As seen in Oedipus' story, the harder one tries to circumvent destiny, the quicker one falls into its snare. For example, in Oedipus' fervent desire to live a life free of the sins against his parents prophesized by the oracle, he fled from Corinth where he grew up, thinking that in doing so he would be distancing himself from his parents and could therefore "prevent such terrible predictions from coming true". (Sophocles, 2007, p. 99) This act of resistance only furthered destiny's course. Oedipus ran straight from Corinth to his true parents, killing his father Laius, taking over the city of Thebes and winning his mother's hand in marriage. Had he stayed in Corinth, Oedipus might have avoided meeting his parents and committing those unnatural crimes. He was condemned precisely because he attempted to flee. Victim of his own choices, Oedipus experienced the ironical futility of resistance as Sophocles demonstrates how destiny cleverly exploits one's unwillingness to conform to propagate its own course.

That's not all. The irony continues and intensifies. As Nietzsche observes in The Birth of Tragedy, "in his purely passive behavior the hero [Oedipus] achieves the highest form of activity, which has consequences reaching far beyond his own life, whereas all his conscious words and actions in his life hitherto have merely led to his passivity." (Nietzsche Friedrich, 1999, p. 47) In other words, the more one determines to have control over one's destiny, the less self-determination one actually achieves. This paradoxical irony can be seen in how, in Oedipus Tyrannos, Oedipus, determined to save his city Thebes from pollution, put his whole heart into hunting down the murderer of Laius, but ended up exposing himself as that very same criminal and losing both his rights to kingship and to citizenship. Now an abomination, Oedipus sank into an abyss of guilt and powerlessness and was ordered into exile. Because of his fervent determination to save his city, Oedipus ended up losing that city. However, later in Oedipus at Colonus, in the powerless position of the exile who has to beg for sanctuary, Oedipus gained his greatest power yet from destiny - he held the fates of two cities, Thebes and Athens, in his hands. Furthermore, as Oedipus finally surrendered his will entirely in death, he attained the consummation of his power and desire. He became the sacred protector of a prominent city. Destiny, as it were, is not only tyrannical and manipulating, but also supremely taunting: the more one determines to have power over oneself, the less power one is given; yet, the more completely one surrenders one's will to destiny's supremacy, the more self-determination one achieves and the more one's goals are actualized.

\subsection{Freedom of Will Is a Concept of Questionable Validity}

Even though the will is portrayed as subjugated and ineffectual, one may have felt it safe to assume that one at least possesses the ability to exert self-determination. But it isn't so. With increasing fear the reader proceeds to confront Sophocles' further revelation: the small amount of self-determination we thought we possessed is of questionable validity; in fact, the whole concept of a will that is free to discover, understand, and act upon its 
intentions is illogical and illusory. The idea that one is endowed with freedom of will is based on the assumption that one has control over oneself and one's desires, in short, over one's will. But it isn't so. In slyly molding one's predispositions according to its wishes, destiny dresses itself in compatriot uniform and leads the general into defeating his own army. Indeed, this facet of destiny's potency threatens to overwhelm the individual as it starkly reveals how, since fate and the self are intricately entwined, there can be no clear target of the enemy. Thus there is no way to strike to win, unless one sacrifices oneself in doing so. As a matter of fact, there were opportunities in the play for Oedipus to outrun destiny or to save himself from the knowledge that destiny had outrun him. For instance, in his meeting at the crossroads with Laius, though the other man was the first to provoke by rudely attempting to "force [Oedipus] from the road", Oedipus would not have been consumed "in anger" and lifted up his hand to kill had he not possessed such a hotheaded temperament (Sophocles, 2007, p. 99). This fallibility innate in himself made him prey of destiny's devices. Furthermore, in his confrontation with the prophet Tiresias, Oedipus could have been spared the knowledge of his crime had he listened to Tiresias' insistent advice that what he sought would only "give [himself] pain" and abstained from asking. (Sophocles, 2007, p. 75) Instead, with the stubbornness, the insistency, and the defiance he was endowed with, Oedipus persisted in seeking out his own destruction. Thus it is demonstrated that one cannot adequately take arms against destiny because, to a great extent, one has no control over one's self-determination because one has no control over the self.

\section{The Implied Chances of Escape for Oedipus Only Adds to the Irony and Futilitarianism of the Piece}

\subsection{Sophocles Implies that Oedipus Could Have Evaded Destiny}

Regardless of the thick cloud of pessimism that surrounds man's ability to triumph over fate in Oedipus Tyrannos, there still appears to be glimpses of hope. In fact, Sophocles seems to suggest, through what could have happened in the story, that one's self-determination can change the course of one's life. He keeps reminding us of the taunting opportunities that Oedipus might have seized and saved himself from his misdeeds and consequential suffering. Oedipus' motive for evading destiny was innocent: it arose spontaneously from his piety towards god and man. The flaw was in the way he carried out his project, not in his original impulse. Thus, one cannot help but wonder that, if Oedipus had but carried out his project differently, he could have avoided his woeful downfall. For example, Oedipus mentioned that, at a party, a drunken man had told him that "[Oedipus] was not [his] father's child", (Sophocles, 2007, p. 99) but he only thought it a lie and an insult. So when the oracle told him of the crimes he was destined to commit against his parents, he immediately assumed that he need only stay away from the king and queen of Corinth to prevent that from happening. Had he been more wary, he would have hunted down the truth and avoided the ignorance that led him to killing Laius and marrying Jocasta. Furthermore, since the prophecy prophesized that Oedipus would "lie with his mother", (Sophocles, 2007, p. 108) Oedipus had the choice to control his desires and abstain from intimate contact with older women and could have thus avoided carrying out his destiny. Indeed, the number of possible escapes that slipped through Oedipus' fingers leaves the impression that, had Oedipus chosen his actions differently, he might have circumvented destiny. Thus, Sophocles appears to imply that self-determination can change the course of one's life.

\subsection{Oedipus' Glimpses of Hope Strengthens the Play's Ironical and Futilitarian Tone}

Although Oedipus Tyrannos leaves the reader with the taunting hope that through careful deliberation Oedipus might have managed to change the course of his life, the fact that this hope is not realized but only implied adds a further intensity to the ironical and futilitarian tone of the piece. There were many paths, but Oedipus chose precisely the one that led to misery. It seems as if there were something built into one's nature that makes one drive oneself to suffering. The improbability yet inevitability of Oedipus' destiny suggests that humanity has a particular aptitude to seek out pain without deliberately doing so. If so, is it safe to trust our choices and desires to steer us away from the misfortunes devised by destiny? Can we depend on our self-determination to guide us to happiness and safety, rather than to tribulation? The essentially insecure relation of will to destiny portrayed here snatches away one's anchor of rationalism and subverts the knowable world into chaos. When one can no longer believe in one's impulses and one's ability to satisfy those impulses, what is left for the self?

\section{Exerting Control over Oneself Has Value and Meaning}

Elevation is what's left. Even though Sophocles appears to negate the ability of the will to rival the force of destiny, he does not deny that exerting control over oneself has value. He points out that destiny imbues significance and noble meaning to the will by denying its desires and reducing it to suffering; thus, although one may fail in one's goal of happiness, one may gain dignity in failure. Oedipus, when he received the blow of destiny and realized what atrocities he was unintentionally guilty of, temporarily gave himself to misery, raving 
and blinding his eyes. It appeared to everyone that he "would have been better dead than living as... [he was] living now" as an abomination. (Sophocles, 2007, p. 128) But Oedipus did not resort to suicide. He continued to pursue his unhappy life, confronting and coming to terms with his guilt and its consequences. Although Oedipus was annihilated in all social aspects of his identity — his identity as a citizen, a king, a pious man - and even though he had to suffer from the knowledge of his abjection, he was not destroyed in his self. He could accept himself, and he could continue living. The self-knowledge and dignity gained by Oedipus at the cost of happiness points to the gravitas of the will that triumphs even as it loses in the battle against destiny. In fact, the heavenly reward given to the exiled Oedipus in Oedipus at Colonus that made him the sacred protector of Athens symbolizes the magnificence of the dignified self-knowledge gained by Oedipus.

Thus, Oedipus' struggle to exert self-determination was not without significance: in refusing to passively accept the devastation of destiny and in taking arms to fight for a happier, purer life, Oedipus demonstrates the powerful will of the hero which gains dignity in actively seeking self-perfection and living life in his own terms. However, he failed to succeed because he attempted to match the finite nature of humanity against the infinity of destiny. But, in doing so, he gained elevation in the form of self knowledge that gave him strength to live in suffering. He recognized humanity's limitations, but he was willing to accept them with a dignified grace.

Therefore, the suffering of Oedipus, king of Thebes, is elevated to a new realm of meaning. Oedipus, in his awareness of human limitations and his extraordinary forbearance that speaks of a willing humility and a silent conviction of life's value, suffers like a visionary for his great knowledge. Rather than live in comfortable ignorance of life's troubles and humanity's finitude, Oedipus is brave enough to recognize his true relationship to the world of suffering and to live life with the gravitas of one who shoulders humanity's misery of being alive but still continues to enact life's value. He has accepted destiny's challenge: "know thyself", and he has survived in sublimation.

As one who sees the truth of humanity through painful realization, Oedipus is not only a visionary but also a pioneer. He takes on the responsibility of the sufferer and defines what it means to be alive in a world of troubles. Pain brings Oedipus distillation: he is now able to wrestle the fundamental issues at stake in existence, and to set an example of endless encouragement and empathy. As Edith Hamilton once said, no dignity can match that of a suffering soul, and that dignity is what Oedipus ultimately attains as a hero, a visionary, and a courageous pioneer.

\section{Conclusion}

Thus, even as Sophocles details the tyrannical, manipulative, and taunting power of fate and contrasts it sharply with the weak and seemingly meaningless nature of the will, he gives the reader what it takes to understand and come to terms with this bitter condition. As we follow king Oedipus through his suffering and elevation, we feel that the truth of life is cruel, but we have the strength to bear that cruelty.

\section{References}

Ellis, E. S., \& Horne, C. F. (2010). The Story of the Greatest Nations and the World's Famous Events. Nabu Press.

Nietzsche, F. (Trans. Ronald Speirs). (1999). The Birth of Tragedy. Cambridge: Cambridge University Press.

Sophocles (Trans. David R. Slavitt). (2007). The Theban Plays of Sophocles. New Haven and London: Yale University Press.

Hamilton, E. (1993). The Greek Way. New York and London: W. W. Norton \& Company.

Schelling, F. W. J. (1989). The Philosophy of Art. Minneapolis: University of Minnesota Press.

\section{Copyrights}

Copyright for this article is retained by the author(s), with first publication rights granted to the journal.

This is an open-access article distributed under the terms and conditions of the Creative Commons Attribution license (http://creativecommons.org/licenses/by/3.0/). 